\title{
Development and Implementation of Online Learning Blended Learning in Business Communication Courses
}

\author{
Revi Marta ${ }^{1, *}$ Ilham Havifi $^{2}$
}

\author{
${ }^{1}$ Communications Science, Faculty of Social and Political Science, Andalas University,Padang 25164, Indonesia \\ ${ }^{2}$ Communications Science, Faculty of Social and Political Science, Andalas University,Padang 25164, Indonesia \\ *Corresponding author. Email: unirevi@gmail.com
}

\begin{abstract}
The Covid-19 pandemic makes online development and implementation research vital as the development of the industrial era 4.0 requires lecturers to be able to develop technology-based learning content and be able to develop learning and assessment methods by utilizing Information and Communication Technology in the learning process. The Business Communication course is a subject that can support this research, which is a review of business communication in a company, communication strategies in winning business, and effective communication planning in business implementation. The learning methods chosen for courses during the Covid-19 Pandemic, which require to study at home, are selected with project-based learning methods because they require students to do business using effective communication. It is necessary to formulate appropriate learning methods, learning technology that supports the teaching and learning process, and an appropriate assessment formula so that the expected outcomes can be achieved. So that after completing the teaching and learning process in the business communication course, it can run well during the Covid-19 pandemic.
\end{abstract}

Keywords: Blended Learning, Communication business, Covid-19

\section{INTRODUCTION}

This year's online development and implementation research (P3D) is considered important as the development of the industrial era 4.0 requires lecturers not only to be able to develop technology-based learning content but also to be able to develop learning and assessment methods by utilizing Information and Communication Technology in the learning process. Andalas University already has an adequate learning management system (LMS) platform for e-learning using the Moodle application called interactive learning (i-learn). However, not many lecturers have used this LMS even though UNAND academic regulation No. 1 of 2019 article 8 , paragraph 8 , states that lectures can be done using Blended Learning.

Its use was only intensive after the Chancellor's policy of study from home (SFH) or Learning From Home (BDR) to avoid the Corona Virus Disease (COVID) 19 pandemic. Following the Chancellor's policy to overcome the COVID 19 pandemic with 2,860 student respondents and 211 lecturers. The survey results show that the learning media most widely used by lecturers is Whatsapp while Zoom is in second place, ilearn is in third place, Google classroom is 4th, and Skype is in fifth place. The number of lecturers using Whatsapp for online lectures is understandable because it has been used in lecturers' daily activities. The lecturers feel most comfortable using this media than other media even though it is difficult to document their learning activities. To encourage lecturers to develop and organize e-learning by utilizing LMS UNAND, LP3M UNAND took the initiative to provide a grant for Research Development and Implementation of Blended Learning (PBLENDED LEARNING Research Grant) in 2020 .

Business communication is a compulsory subject in the Communication Science Study Program. This course weights three credits (2-1) wherein this course, students have to get hard skills and soft skills, there is a combination of theory and practice where the portion of the practice is more significant than theory. The business communication course is a compulsory subject in several departments at Andalas University. Because 
this course follows the vision and mission of Andalas University, which is very thick with its entrepreneurial base and under the Department of Communication Sciences' vision. For this reason, it is indispensable to research the Development and Quality Assurance of Education (PPMP) so that later RPS, learning methods and technology, as well as adequate student assessments, are needed to create students who have a good business spirit.This Communication Business course is a compulsory subject in semester 4 for all communication science department concentrations. Elements of learning outcomes include knowledge of the Communication Business, attitudes and values in lectures, and hard skills and soft skills (intrapersonal skills and interpersonal skills). Learning methods developed to support learning outcomes in group discussions, review and presentation of materials, case studies, and questions and answers related to business communication.

This course is an overview of business communication in a company, communication strategies in winning business, and effective communication planning in implementing business. Business and communication cannot be separated; a business activity may not run well without good communication. This subject also discusses interpersonal communication in the communication business; even though the technology is already sophisticated, a communication person in business must control it.

The general objective of learning this business communication course is students are expected to understand the business communication concepts that consist of; explore and discuss in the form of business communication process seminars and the role of interpersonal communication in business communication. Students are expected to understand message design in business communication and design messages. Then, students can make proposals and business reports.

After taking this course, students are expected to obtain and achieve learning outcomes, namely being able to understand business communication concepts, understand and apply interpersonal communication in business communication. From the soft skill aspect, students are also expected to write review/essay results. Well, able to present the results of his thoughts confidently, independently, has discipline, ethics, and can work in a team.

The learning methods that can be chosen for implementing learning courses during the Covid-19 Pandemic, which require us to study at home, are chosen with project-based learning methods. Because this course requires students to do business using effective communication, it is necessary to formulate appropriate learning methods, learning technology that supports the teaching and learning process, and an appropriate assessment formula so that the expected outcomes can be achieved. So that after completing the teaching and learning process in the business communication course, it can run well during the Covid19 pandemic.

\subsection{Methodology or Strategy for Achieving Outputs}

The method used is the development and implementation of online learning (P3D), which means that a person/person who develops and organizes online learning (P3D). The research design used is the development and implementation of online learning (P3D) are also involved in the process and then consciously carry out programs that have been designed to completion (Suwarsih, Madya, 1994). The development and implementation of online learning (P3D) have many variants of learning that are contextualized in the class or space used in the teaching and learning process carried out by lecturers to solve problems faced by lecturers in the learning process, improve hard skills and soft skills students by continuing to innovate using learning techniques to improve the quality and student achievement. The development and implementation of online learning (P3D) use qualitative methods in collecting and analyzing data.

\section{BACKGROUND}

In the design of research development and implementation of online learning (P3D), researchers are involved in the learning process, looking for and finding specific actions in the classroom, implementing actions deemed suitable for the classroom atmosphere, and supporting learning materials and techniques.

The technique of collecting data is through participatory observation in which researchers are actively involved and become part of the development and implementation of online learning (P3D). Other techniques in collecting research data are also through interviews, documentation, and questionnaires. The type of development and implementation of online learning (P3D) is collaborative. The researcher is also the teaching team to plan, identify, observe, and carry out the actions that have been designed. The research design used was the development and implementation of online learning (P3D) using Blended Learning.

Plans to develop learning methods and assessment of e-learning that are effective in achieving learning outcomes. The development of online learning and assessment methods should produce the same or better results than conventional learning and assessment methods. In the RPS / RPB, it is necessary to explain the 
selected learning activities, whether virtual synchronous or asynchronous (independent or collaborative) and appropriate learning technology media to achieve learning outcomes. E-learning assessment of learning outcomes must refer to the SNPT, which includes process and outcome assessment, by selecting assessment techniques according to the level of competence planned in the RPS / RPB.

\subsection{RPS / RPB Blended Learning Plan}

So that the output of this research is in the form of (i) new RPS; and (ii) articles on the results of Research on Development and Quality Assurance of Education (PPMP) from the development of learning methods, curricula, learning technology, and student assessments, the achievement strategies will be explained as follows:

\section{1) Lesson Plan}

As outlined in the previous RPS, the lesson plans were less comprehensive regarding all components of learning outcomes starting from changing attitudes, increasing knowledge, and mastery of skills. All of this must be summarized in detail and clarity in the revised RPS. Also, a learning plan will be formulated which contains the following details: 1) The learning process activities that will be carried out by the lecturers which will become a learning experience for students; 2) systematic learning steps so that learning objectives can be achieved; 3) The learning steps are arranged in detail so that if other lecturers use the RPS, it is easy to understand and does not cause multiple interpretations. This is expected to be used as a guide for lecturers and students in the learning process going forward. The learning approach that is carried out in this classroom action research is the SCL approach, with a projectbased learning method.

\section{2) Development of Learning Methods}

The learning method developed in the development and implementation of online learning (P3D) is a learning method based on Blended Learning (Blended Learning). This systematic learning method invites students to learn knowledge and skills through a structured inquiry process about questions and products, and tasks. Which are complex, authentic, and carefully designed.

Blended Learning is a learning method that directs students, through Blended Learning, to develop thinking power, find their way of solving problems, develop collaboration skills, browse literature, convey information, and conduct their friends' evaluations.

Blended Learning-Blended Learning is developed from real situations in everyday life so that the curriculum becomes more exciting and meaningful. Blended Learning is an individual or group activity within a specific timeframe (one semester or shorter) due to a product, presentation, or written work. Blended Learning elements, including:

\section{3) Development of Student Assesment}

Learning achievement is a student's ability, manifested through the mastery of knowledge, attitudes, and skills, which they acquire during the learning process. Learning achievement is used as a description of success for students to understand certain subjects. Every effort made in learning activities aims to achieve the highest learning achievement (mastery of hard skills and soft skills). A value score expresses learning achievement.

\section{4) Curriculum}

The Communication Business course is a compulsory subject in the Communication Science Study Program, which is part of the KKNI-based curriculum currently used and plans for change.

\subsection{The Proposed Learning Technology Media}

Must be able to replace conventional learning methods better (efficient and practical) in achieving learning outcomes. The learning technology used in this learning process is divided into two, namely communication media and learning media. Communication media are needed to facilitate academic information delivery, namely using the Whatsapp application and other social media (online media that support business activities), which will be used as a medium of interaction for lecturers and students and between students in discussing and delivering lecture assignments. The Unand i-learning application will also be used to upload and download various lecture materials and assignments given by lecturers. This study also uses ICT technology in the form of an online form that students can fill in in response to lecturer questions.

The learning technology used in this learning process is divided into two, namely communication media and learning media. Communication media is needed to facilitate the delivery of academic information, namely using the Whatsapp application and other social media (online media that support business activities), which will be used as a medium of interaction for lecturers and students and between students in discussing and delivering course assignments. The Unand i-learning application will also be used, which can upload and download various lecture materials and assignments given by lecturers. This study also uses ICT technology in the form of an online form that students can fill in in response to lecturer questions.

The technology used as a learning medium in every practical meeting of media facilities found on the 
internet, namely social media that provides content (photos or videos), including Instagram, Youtube, Twitter, Facebook, and similar social media applications that support film videos and other social media so that can support students to be competent in doing business. The learning technology is used as a practicum medium for business communication courses.

Picture 1. Ilearn Bussiness Communications Course

\section{RESEARCH RESULT}

\subsection{Business Communication Lecture}

This course analyzes how the COMMUNICATION BUSINESS lecture contributes to the way public relations government faces crises and problems, community service, and online-based public relations performance adjustments. The Business Communication course, which is abbreviated as Communication Business, is a course in the Department of Communication. It provides hard skills and soft skills. There is a combination of theory and practice where the practice portion is directly proportional to theory. Therefore, this course is deemed necessary so that later RPS, learning methods, and technology are produced and adequate student assessments to realize student independence.

The learning method for this Business Communication course uses Collaborative Learning, which collaborates learning techniques to work together with others. Collaborative learning practice means working in pairs or small groups to achieve shared learning goals. Collaborative learning means learning through group work, not learning in isolation.

\subsection{Description of Business Communication Learning Outcomes}

For conceptual achievements, students expected to have an understanding of the relation to the concept of public relations in the COMMUNICATION BUSINESS study, including understanding various elements of government public relations, then identifying differences, similarities, and phenomena in public relations studies, and being able to analyze, both conceptually and practically, assessing the development of the existing public relations system. and use it as a source of excellence in government public relations today in the practical and academic world. From the soft skill aspect, students are also expected to write good reviews/essays, present the results of their thoughts, be confident, be independent, have discipline, ethics, and work in teams.

\subsection{Learning Objectives}

The general objectives of learning the Communication Business course:

1. Understand the various public relations concepts in the Government Public Relations study.

2. Able to identify linkages between media relations and public information campaigns with government information service systems to the public.

3. Knowing and explaining the current development of government public relations in establishing onlinebased public disclosure and Web 2.0.

4. Knowing and explaining the current development of government public relations in establishing onlinebased public disclosure and Web 2.0.

\subsection{Research Results and Discussion}

This research was conducted in 2 cycles; each cycle carried out the following procedures: planning, implementing actions, observing, and reflecting. Through these two cycles, it can be observed that the students' ability increases using various media. The first cycle with interactive learning assessment in the field and the second cycle of online learning (the assessment reporting stage using the portal ilearn.fisip.unand.ac.id).

\subsubsection{Cycle I Business Communication Lecture Process Activities}

Lectures in Communication Business course can collaborate online learning and interactive learning as known as Collaborative Learning Method, in order that students expected to have an understanding of the relationship between public relations activities directly in the study of COMMUNICATION BUSINESS in the era of technology 4.0, including understanding various elements of government public relations, then identifying differences, equations, and phenomena in the study of public relations.

Students can also analyze, both conceptually and practically, to assess the development of the existing public relations system and use it as one of the sources of excellence in current government public relations in the practical and academic world.

From the table of assessors above, hard skills and soft skill aspects are expected to be able to write good reviews/essays, present the results of their thoughts, be confident, be independent, have discipline, ethics, and work in teams. By interacting directly, the field visits government agencies in establishing relationships and 
community services. Lecture activities can be seen in the following picture:

1. Students nowadays do not easily focus on learningbecause they cannot manage the use of gadgets

2. This course is a course that analyzes the performance of the government, namely the Public Relations Division

3. Lecturers still considering students' soft skills can be fulfilled with the appropriate learning technology.

4. Lectures are the dominant practice of producing content that requires a computer laboratory, as well as supporting hardware and software

These obstacles formulate appropriate learning methods, learning technology that supports the teaching and learning process, and the right assessment formula so expected output can be achieved. So that after completing the teaching and learning process in the COMMUNICATION BUSINESS course, all students have the maximum score.

The Hopkins model's research design begins with preliminary action then continues with planning, action, observation, and reflection. The research was conducted in 2 cycles. The evaluation results in cycle I were still incomplete, so improvements were made in cycle II. Reflection cycle II is carried out to determine steps for improvement in cycle II. Reflection cycle I is carried out to determine steps for improvement in the cycle. The research stages carried out are as follows:

\section{1) Planning}

Activities carried out at the planning stage include:

1. Develop a lesson plan using the debate method as a corrective action in learning

2. Prepare learning media in the form of case sheets and contemporary issues concerning Public Relations (Business Communication)

3. Develop observation guidelines

4. Develop student evaluation tools.

2) Action

1. Initial Activities
In the initial activity, the lecturer prepared to learn media and invited students to read the cases presented. Then arouse students' enthusiasm for learning by asking questions and answers about the issues given.

\section{Final Activity}

At the end of the lesson, the lecturer concludes the learning outcomes and explains the benefits of learning through a collaborative based learning method. Moreover, students have completed the specified project.

3) Observation (Observation) of Field Public Relations Activities

The observation involved several parties, including members of the lecturer team, researchers, and peers. The observation was carried out during the learning process based on the researcher's observation sheet. Things that must be observed by observers are student activities during the learning process, and the learning process can be carried out following the learning implementation plan. Furthermore, an analysis of the results of observations was carried out to determine students' activeness, lecturers, and the course of learning.

\section{4) Reflection}

All observations, student evaluations, and field notes were analyzed, explained, and concluded at the reflection stage. The purpose of reflection is to determine the success of the project-based learning process using various media technologies.

\section{DEVELOPMENT TEAM}

The development team is team teaching in the Business Communication course, namely:

Chairman: Revi Marta, M.I.Kom

Duties in Team Teaching:

1. Prepare RPS

2. Delivering lecture materials

3. Facilitating the learning process

4. Prepare the practicum module

5. Prepare Blended Learning media production

6. Prepare for the Blended Learning workshop 
7. Prepare for the final semester exams

8. Checking exam results

9. Give students final grades

Education: S1 Communication Science, Yogyakarta State Development University

Padjadjaran University's Master of Communication Science

Rank: Expert Assistant

Group: III b

Certificate: Pekerti and AA

Training: I Learn

\section{SKKNI}

Entrepreneurship TOT

Member 1: Ilham Havifi, S.I.Kom, M.I.Kom

Duties in Team Teaching:

1. Assisting the team leader in preparing the RPS

2. Delivering lecture materials

3. Facilitating the learning process

4. Assisting the team leader in preparing the practicum module

5. Help prepare business Blended Learning

6. Help prepare for the Blended Learning Week for UKM and UMKM

7. Prepare for midterm exams

8. Check the exam results

Education: S1 Communication Science, Riau University

Master of Communication Science, Andalas University

Rank: Stylist

Group: III b

Certificate: Pekerti and AA
Training: I Learn

SKKNI

\section{CONCLUSION}

Its use was only intensive after the Chancellor's policy of study from home (SFH) or Learning From Home (BDR) to avoid the Corona Virus Disease (COVID) 19 pandemic. Under the Chancellor's policy to overcome the COVID 19 pandemic with 2,860 student respondents and 211 lecturers. The survey results show that the learning media most widely used by lecturers is Whatsapp while Zoom is in second place, ilearn is in third place, Google classroom is 4th, and Skype is in fifth place. The number of lecturers using Whatsapp for online lectures is understandable because it has been used in lecturers' daily activities. The lecturers feel most comfortable using this media than other media even though it is difficult to document their learning activities. To encourage lecturers to develop and organize e-learning by utilizing LMS UNAND, LP3M UNAND took the initiative to provide a grant for Research Development and Implementation of Blended Learning (PBLENDED LEARNING Research Grant) in 2020 .

Business communication is a compulsory subject in the Communication Science Study Program. This course has a weight of 3 credits (2-1) where in this course students not only have to get hard skills and but also soft skills, there is a combination of theory and practice where the portion of practice is bigger than theory. The business communication course is a compulsory subject in several departments at Andalas University. Because this course is in accordance with the vision and mission of Andalas University which is very thick with its entrepreneurial base and in accordance with the vision of the Department of Communication Sciences. For this reason, it is very necessary to carry out research on the Development and Quality Assurance of Education (PPMP) so that later RPS, learning methods and technology, as well as adequate student assessments are needed to create students who have a good business spirit.

The learning methods that can be chosen for the implementation of learning courses during the Covid-19 Pandemic which require us to study at home are chosen with project-based learning methods, because this course requires students to be able to do business using effective communication, it is necessary to formulate appropriate learning methods, learning technology that supports the teaching and learning process, as well as an appropriate assessment formula so that the expected outcomes can be achieved. So that after completing the teaching and learning process in the business communication course, it can run well during the Covid19 pandemic. 


\section{REFERENCES}

[1] Arikunto, Suharsini, dkk. 2007. Penelitian Tindakan Kelas. Jakarta: Bumi Aksara.

[2] Alsa, Asmadi. 2003. Pendekatan Kuantitatif \& Kualitatif Serta Kombinasinya dalam Penelitian Psikologi. Yogyakarta. Pustaka Pelajar. [3] C. Baier, J-P. Katoen, Principles of Model Checking, MIT Press, 2008.

[3] Berlo, David K. 1960. The Process of Communication: An Introduction to Theory and Practice. New York:Holt, Rinehart and Winston.

[4] Bungin, Burhan (Ed.). 2008. Metodologi Penelitian Kualitatif. PT.Raja Grafindo Persada. Jakarta.

[5] Cangara, Hafied. 2009. Pengantar Ilmu Komunikasi. PT.Raja Grafindo Persada. Jakarta.

[6] Effendi, Onong Uchjana. 1993. Ilmu, Teori, dan Filsafat Komunikasi. PT.Citra Aditya Bakti.

Bandung

[7] Hamijoyo, Santoso S. 2005. Komunikasi Partisipatoris. Humaniora. Bandung.

[8] Harapan, Edi dan Ahmad, Syarwani. 2014. Komunikasi Antarpribadi: Perilaku Insani Dalam Organisasi Pendidikan. PT Raja Grafindo Persada. Jakarta.

[9] Littlejohn, Stephen W and Foss, Karen A. 2009. Teori Komunikasi. Penerjemah: mohammad Yusuf Hamdan. Salemba Humanika. Jakarta.

[10] Mulyana, Deddy. 2008. Ilmu Komunikasi: Suatu Pengantar. PT Remaja Rosdakarya. Bandung.

[11] Nasution, S. 1992. Metode Penelitian NaturalistikKualitatif.TARSITO. Bandung.

[12] Rubiyanto, Rubino. 2011. Metode Penelitian Pendidikan. Surakarta: FKIP UMS.

[13] Sugiyono. 2012. Metode Penelitian Pendidikan. Bandung: Alfabeta.

[14] Suwarsih, Madya. 1994. Panduan Penelitian Tindakan. Yogyakarta: Lembaga Penelitian IKIP Yogyakarta.

[15] Tubbs, Stewart L dan Moss, Sylvia. 2012. Human Communication. Penerjemah: Deddy Mulyana. PT Remaja Rosdakarya. Bandung. 